University of Rhode Island

DigitalCommons@URI

The Rhode Island Current Conditions Index

Economics

$1-2008$

\title{
Rhode Island Current Conditions Index - January 2008
}

Leonard Lardaro

University of Rhode Island, lardaro@uri.edu

Follow this and additional works at: https://digitalcommons.uri.edu/ricci

Part of the Econometrics Commons

Terms of Use

All rights reserved under copyright.

\section{Recommended Citation}

Lardaro, Leonard, "Rhode Island Current Conditions Index - January 2008" (2008). The Rhode Island Current Conditions Index. Paper 60.

https://digitalcommons.uri.edu/ricci/60

This Article is brought to you for free and open access by the Economics at DigitalCommons@URI. It has been accepted for inclusion in The Rhode Island Current Conditions Index by an authorized administrator of DigitalCommons@URI.For more information, please contact digitalcommons-group@uri.edu. 


\section{BURRENT}

Rhode Island began 2008 with a bang. Not from an explosion, but from an implosion. Not only were the revisions to labor market data for 2007 downward, as I had anticipated, they were far worse than I or anyone else had imagined. As a result, many of the Current Conditions Index values for 2007 were revised lower. The one thing that remained intact, unfortunately, is the inescapable conclusion that Rhode Island fell into recession during 2007.

The Current Conditions Index for January of 2008 tied its lowest value ever, 8 , which places it in the contracting range for the sixth consecutive month (after posting an upwardly revised value of 58 in July). Only one indicator improved in January, the Manufacturing Wage, which grew at a very rapid rate $(+3.9 \%)$. Ironically, this signals ongoing skills shortages in Rhode Island's manufacturing sector. Don't take this as indicating manufacturing strength here. For January, Total Manufacturing Hours fell by 5.9 percent, its most rapid rate of decline in years.

What does such a low value for the $\mathrm{CCl}$ indicate? Think of the number of improving indicators in a given month as how many "legs" economic activity here is standing on. The $\mathrm{CCl}$ thus reflects the underlying momentum of our state's economy, not the overall level of activity. After last July, the carpet was pulled from under our state's economy. So, while the levels of

\begin{tabular}{|l|r|}
\hline \multicolumn{2}{|c|}{ CCI Indicators - \% Change } \\
\hline Government Employment & -0.3 \\
\hline US Consumer Sentiment & -19.2 \\
\hline Single-Unit Permits & -55.1 \\
\hline Retail Sales & -1.5 \\
\hline Employment Services Jobs & -5.1 \\
\hline Priv. Serv-Prod Employment & -0.3 \\
\hline Total Manufacturing Hours & -5.9 \\
\hline Manufacturing Wage & 3.9 \\
\hline Labor Force & -0.6 \\
\hline Benefit Exhaustions & 23.9 \\
\hline New Claims & 10.3 \\
\hline Unemployment Rate & 16.3 \\
\hline \multicolumn{2}{|c|}{ Y $=$ Improved Value } \\
\hline
\end{tabular}

a number of key indicators are still at fairly high levels, those levels have become increasingly unsustainable, as indicated by values of the $\mathrm{CCl}$ in the contracting range (below 50). As I conjectured last month, Rhode Island has indeed moved beyond the early recession stage. Things aren't going to get better than they are now for some time. And, just like Rhode Island made a bad situation worse in the 1989 recession (national recession plus a state banking crisis), we have once again made things worse: add a self-imposed budget crisis added to the national and state recessions. Clearly, our state's economy won't begin to move forward as soon as it could have and should have.

My econometric analysis seeing a downward revision to payroll employment was not only correct - my estimates proved to be exceedingly optimistic. Payroll employment for December of 2007 saw a sharp downward revision of almost 6,000. More importantly, two $\mathrm{CCl}$ indicators were revised lower. Employment Service Jobs, a leading labor market indicator that includes "temps" was revised down so that it failed to improve in any month of 2007. Private Service Producing Employment was also lowered, registering a series of declines that began in September. And, not very surprisingly, our Unemployment Rate was revised higher for several months. All of these lowered CCl values for several months of 2007.

Overall, there was no shortage of disappointing performances in January. Among these, US Consumer Sentiment fell by 19.2 percent, and Retail Sales posted its six consecutive decline, but by a noticeably slower rate of only 1.5 percent.

Let me end on somewhat of a positive note. For January, Single-Unit Permits fell by 55.1 percent. While that sounds disastrous, there must be less new home construction before we can reduce our bloated inventory of unsold homes. So, this is a very early step in the healing of our housing sector's woes.

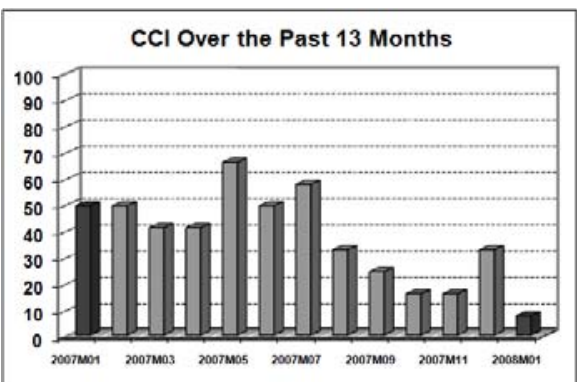

\section{THE BOTTOM LINE}

Rhode Island's economy began 2008 devoid of any momentum. Its transition beyond the initial recovery stage is now well under way, which will make the current levels of many important economic indicators increasingly unsustainable. Rhode Island's self-imposed budget crisis will only make this difficult situation worse.

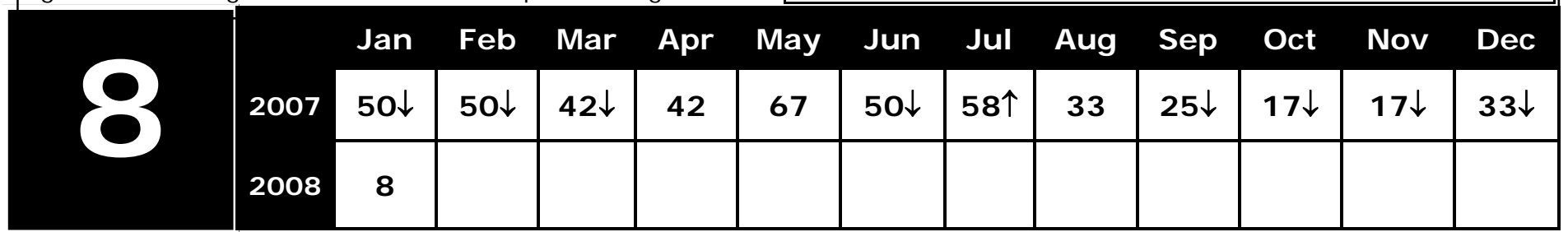

